УДК 504.45(285.3):613.3 (477.74)

(C) 2016

Степова О. В., кандидат технічних наук,

Рома В. В., старший викладач

Полтавський національний технічний університет імені Юрія Кондратюка

\title{
ОЦІНКА БІОГЕННОГО ЗАБРУДНЕННЯ ПОВЕРХНЕВИХ ВОДОЙМ ПОЛТАВСЬКОЇ ОБЛАСТІ
}

\section{Рецензент - кандидат технічних наук Ю. С. Голік}

У роботі виконана екологічна очінка стану річкових вод та проведено аналіз останніх досліджень $i$ публікацій щзодо екологічного стану річкових систем у Полтавській області. Досліджено динаміку вмісту біогенних елементів у поверхневих об'єктах Полтавської області. Проведено аналіз проблем евтрофікаиії поверхневих водойм на регіональному рівні. Запропоновано основні заходи щуодо обмеження використання миючих засобів, своєчасного контролю за очисним обладнанням, його модернізацією $і$ орієнтування на Європейські норми якості, що дасть змогу регулювати та контролювати потрапляння фосфатів зі стічними водами до поверхневих водойм.

Ключові слова: поверхневі води, індекс забруднення води, біогенні елементи, евтрофікація, стан водних ресурсів.

Постановка проблеми. Проблема стану водних ресурсів $є$ однією з найактуальніших проблем розвитку усієї економіки України на найближчі роки, особливо у випадку необхідності забезпечення питних потреб.

Інтенсифікація господарської діяльності - одна 3 обов'язкових умов подальшого розвитку людського суспільства - супроводжується безумовним посиленням антропогенного впливу на довкілля. Однією з найбільш вразливих його ланок є води місцевого стоку - малі річки та водотоки.

Одним із наслідків високого антропогенного впливу є евтрофікація водойм. Це складний процес у прісних і морських водах, де бурхливий розвиток певних типів мікроводоростей порушує водні екосистеми і являє собою загрозу тваринам і здоров'ю людини.

Погіршення екологічної ситуації річкових систем у Полтавській області внаслідок нераціонального використання водних ресурсів, значного техногенного впливу є вкрай відчутною проблемою і несе приховану небезпеку для нинішнього і майбутніх поколінь.

Екологічні ризики від господарської діяльності, що проводяться в Полтавській області, зумовлюють необхідність застосування комплексного підходу для вивчення тенденцій зміни якісних показників поверхневих вод.

Найбільшу увагу викликає вивчення надходження та розподілу у водах місцевого стоку біогенних речовин, особливо сполук азоту і фосфору. Адже вони є хімічними каталізаторами процесу антропогенного евтрофування поверхневих вод, який у наш час вже досяг глобального, планетарного масштабу. Він характеризується різким збільшенням біомаси водоростей, вищої водної рослинності, фітопланктону за рахунок надходження поживних біогенних речовин антропогенного генезису. В результаті біохімічного розкладу цієї біомаси у воді річок та водосховищ може виникати, починаючи 3 другої половини літа, дефіцит кисню, що супроводжується заморними явищами і являє собою значну загрозу для життєдіяльності багатьох гідробіонтів. Окрім того, в результаті розкладу рослинних організмів у воду надходять токсичні речовини, небезпечні як для тварин, так і для людини.

Аналіз сучасного екологічного стану водних джерел Полтавської області свідчить, що негативні процеси на річках, водосховищах і ставках тривають. Більшість річок і водотоків забруднені хімічними, а саме біогенними речовинами, які потрапили у водойми внаслідок скиду стічних вод промислових підприємств, втратили своє природне значення. Проблема якісного виснаження водних ресурсів 3 кожним роком стає більш гострою. Основні труднощі під час використання поверхневих водних джерел пов'язані iз забрудненням та евтрофікацією водойм. Проблема евтрофікації стосується екологічної безпеки водних об'єктів, тому є найактуальнішим питанням сьогодення.

Аналіз останніх досліджень і публікацій, у яких започатковано розв'язання проблеми. Вивченню вмісту та стоку біогенних речовин річок України присвячено роботи О. М. Алмазова [1], О. І. Денисової [2], О. П. Нахшиної [3]. Дані про стік біогенних речовин р. Горині присутні в роботі Д. Коненко, І. Г. Гарасевич, I. Г. Енакі [4]. Характеристика біогенних елемен- 


\section{TEХНIЧНI НАУКИ}

тів для Нижнього Дніпра подана в роботі Л. О. Журавльової [5], а особливості формування вмісту біогенних речовин та характеристик їх стоку у річках басейну Дніпра - в роботі C. І. Сніжка [6]. Аналізу якісного стану поверхневих водних джерел Полтавської області присвячено багато наукових праць [7-9]. Оцінити якісно стан поверхневих вод, що знаходиться під впливом людської діяльності, є досить складним завданням, оскільки він визначається багатьма факторами. Визначення одночасно всіх показників не завжди $\epsilon$ необхідним та економічно доцільним. Практично залежно від мети досліджень оцінка якості поверхневих вод грунтується на обраних репрезентативних показниках, величини яких мають визначатися за уніфікованими методами аналізу якості компонентів довкілля.

Метою досліджень $\epsilon$ оцінка біогенного забруднення поверхневих вод Полтавської області.

Завданням дослідження є визначення практичних заходів та їх розробки для зменшення антропогенно-біогенного забруднення поверхневих водних джерел Полтавської області.

Об'єкт дослідження - поверхневі водні об'єкти Полтавської області.

Матеріали і методи досліджень. Аналіз біогенного забруднення поверхневих вод виконано на основі даних спостережень за вмістом гідрохімічних (біогенних) показників, наданих Полтавським регіональним управлінням водних ресурсів.
Результати досліджень. На території Полтавської області налічується 146 річок (водотоків довжиною понад 10 км) загальною довжиною 5100 км.

Основними джерелами водних ресурсів області є річки Сула, Псел, Ворскла, Оріль та їх притоки, а також Кременчуцьке та Дніпродзержинське водосховища на річці Дніпро. У межах області формується стік трьох річок: Сліпорід, Говтва, Тагамлик.

Проведено оцінку якісного стану поверхневих водних джерел Полтавської області за комплексним показником забруднення IЗB за період 2000-2014 pp., із урахуванням наступних гідрохімічних показників: загальне залізо, нітрити, амоній-іони, фосфати, БПК, нафтопродукти [7].

За результатами оцінки якості річкових вод Полтавської області за середніми значеннями показника індексу забруднення води (I3В) в Полтавській області станом на 2014 рік не існує поверхневих водойм, які відносяться до категорії «чиста» або «дуже чиста» (рис. 1). У цілому, рівень забруднення поверхневих водойм Полтавської області близький рівню екологічної катастрофи [8].

Найбільш забрудненою вважається річка Суха Лохвиця (I3B=7,14, категорія водойми - VI - дуже брудна $(6<$ I3В < 10)) [9].

Одними з вагомих забруднюючих речовин, які суттєво збільшують індекс забруднення води є біогенні елементи: фосфат- та нітрат-іони.

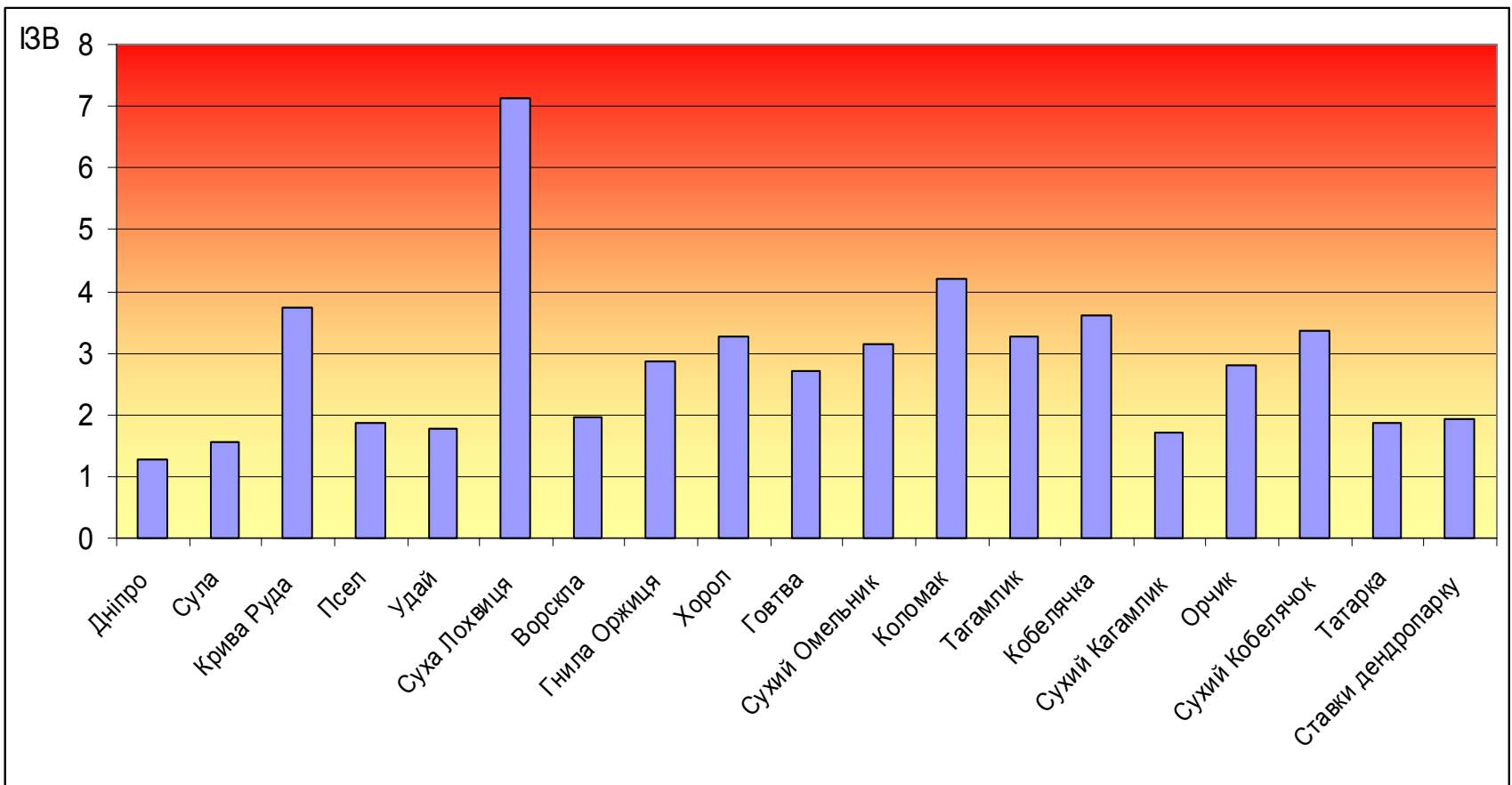

Рис. 1. Динаміка середнього індексу забруднення води в поверхневих водних джерелах Полтавськоӥ області в період 2000-2014 pp. 


\section{ТЕХНІЧНІ НАУКИ}

Ступінь вагомості даних елементів визначена за допомогою коефіцієнта кореляції відносно вмісту зазначених елементів у воді досліджуваних об'єктів, значення якого коливаються для фосфатів у межах 0,45-0,87 (для річки Суха Лохвиця - 0,87), а для нітрит-іонів - 0,6-0,9 (для річки Суха Лохвиця - 0,9). У всіх, без виключення, поверхневих водоймах Полтавської області спостерігається перевищення фосфатів та нітратів. Максимальна концентрація спостерігається по річці Суха Лохвиця (35 ГДК), а найменша по Річці Дніпро (2,5 ГДК).

Тому в роботі поставлене завдання більш детально оцінити рівень забруднення річки Суха Лохвиця біогенними елементами.
Річка Суха Лохвиця відноситься до класу малих річок. Протяжність по території регіону становить 66,5 км. Уздовж іiі берегової лінії розташовано 3 населених пункти, які прямо чи опосередковано є джерелами надходження забруднюючих речовин у водойму. Основним підприємством-забруднювачем цієї річки є ОК ВПВКГ «Миргородводоканал» Лохвицька дільниця.

Максимальна концентрація фосфатів за досліджуваний період була зафіксована у 2007 році і перевищення сягало понад 30 разів. Середнє перевищення гранично допустимої концентрації за досліджуваний нами період становило більше від норми у 16 разів (рис. 2).

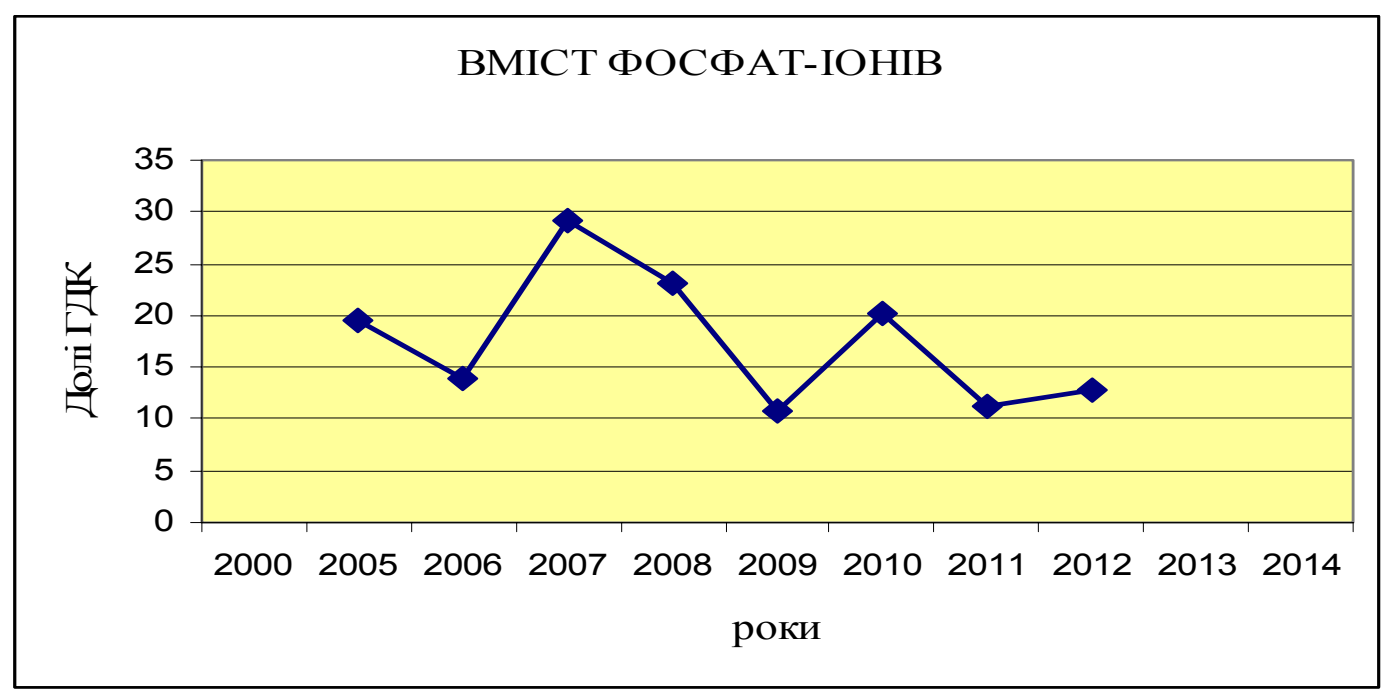

Рис. 2. Стан фосфатного забруднення річки Суха Лохвиця за 2000-2010 роки

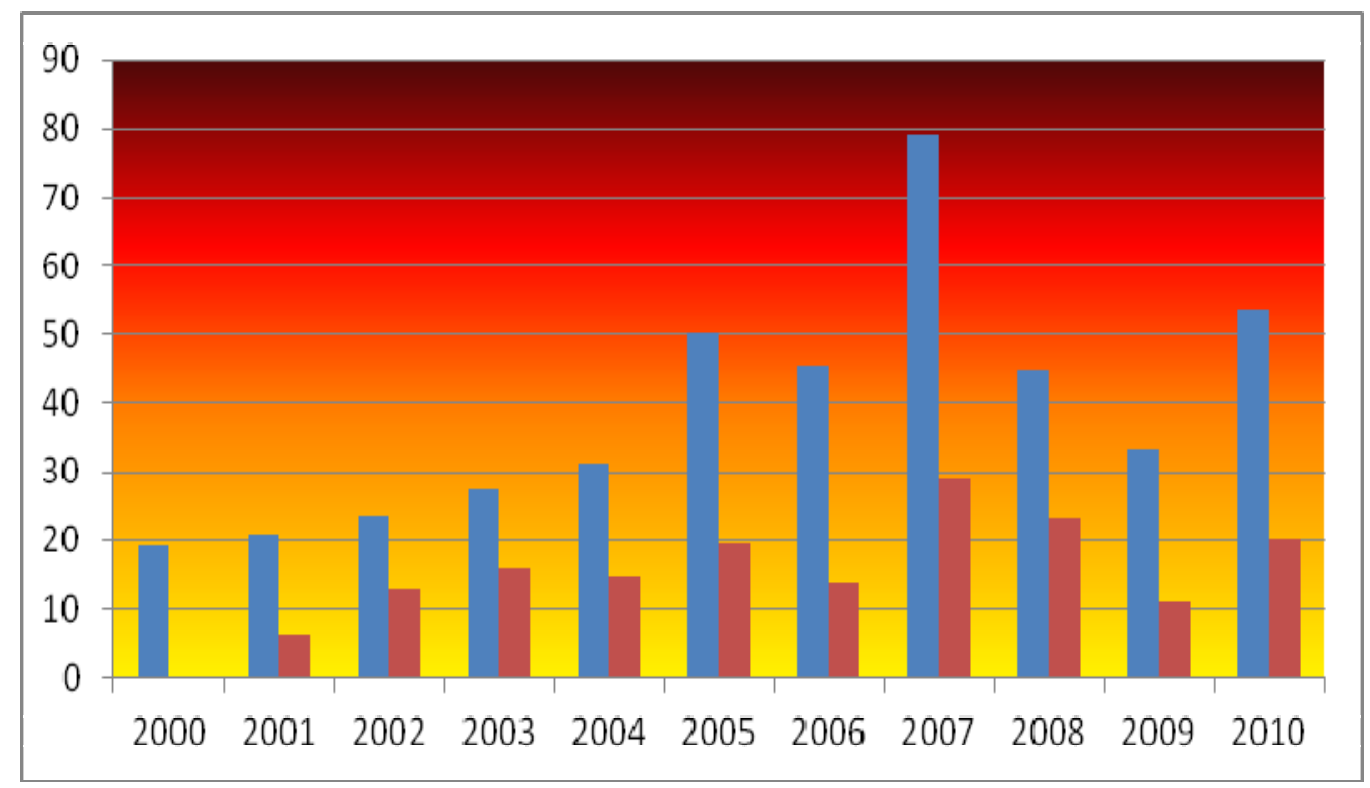

Рис. 3. Частка фосфатів у загальному показнику забруднення річки Суха Лохвиця за 2000-2010 роки 


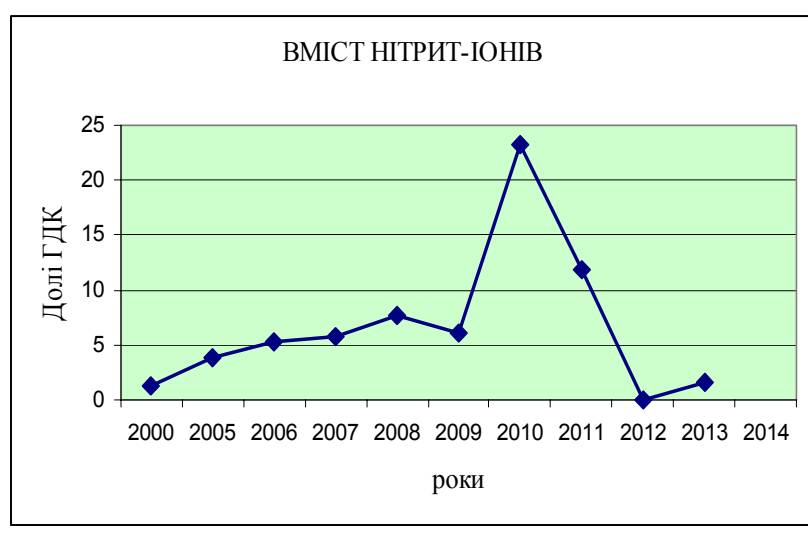

Рис. 4. Динаміка азотвмісних забруднень у створах річки Суха Лохвиця за роками
У роботі визначена частка фосфатів у загальному показнику індекса забруднення води поверхневого джерела (рис. 3).

У досліджуваних створах проаналізовано вміст нітрит-іонів та іонів амонію. Суттєво перевищена концентрація відповідних ГДК іонів амонію (до 23 ГДК), нітрит-іонів (до 25 ГДК) (рис. 4).

Як свідчать результати досліджень, концентрація біогенних елементів в середньому по річках області та по річці Суха Лохвиця значно перевищують допустимі концентрації для водойм даної категорії.

Надходження великої кількості біогенних речовин у прісноводні водойми 3 комунальними, промисловими та сільськогосподарськими стічними водами, із забрудненим поверхневим стоком призводить до евтрофікації цих водойм, що може викликати екологічні зміни із втратою видів водних рослин та риб (погіршення умов існування), несприятливий вплив на стан вод для різних видів водокористування.

I хоча самі по собі фосфор та азот не отруйні, вони призводять до тяжких наслідків, потрапляючи в водні екосистеми, бо сприяють бурхливому розвитку синьо-зелених і бурих водоростей, які споживають велику кількість кисню і т.ч. значно зменшують його вміст у воді. Особливо це відчутно для водних живих організмів у спеку, коли розчинність кисню набагато знижується.

Надзвичайно гострою проблемою водойм $\epsilon$ розмноження ціанобактерій, що тісно пов'язане 3 евтрофікацією. Найбільш відома особливість деяких різновидів ціанобактерій у контексті охорони здоров'я - здатність продукувати токсини (ціанотоксини).

Відомо, що на території Полтавської області основним джерелом надходження фосфору та

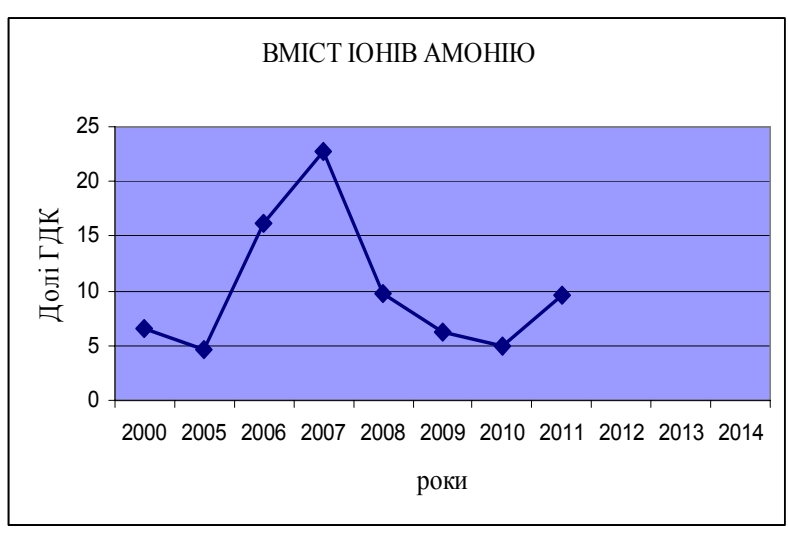

азотовмісних сполук у водойми Дніпра $є$ поверхневий стік 3 площі водозабірного басейну річок та скиди комунальних стічних вод. Одним 3 постійних джерел надходження біогенних забруднюючих речовин у водні об'єкти є міські стічні води, 3 яких за загальноприйнятих технологій біологічного очищення не забезпечується видалення фосфору до необхідних нормативів. Більшість споруд очищення міських стоків, що діють, засновані на застосуванні традиційної біотехнології, що дають низьку ступінь вилучення фосфатів (до 20-30 \%). У результаті на багатьох об'єктах нормативи скидання фосфору не виконуються.

Висновок. Враховуючи зазначене вище, слід негайно впроваджувати практичні заходи, які б могли покращити гідроекологічний стан річок. Умовно заходи щодо зменшення біогенного забруднення водних об'єктів Полтавської області можна поділити на три групи:

1. Заходи щодо зменшення біогенного забруднення спричиненого діяльністю сільськогосподарського комплексу;

2. Заходи щодо зменшення біогенного забруднення промисловим комплексом;

3. Заходи щодо зменшення біогенного забруднення господарсько-побутовим комплексом.

Основними заходами для зменшення антропогенно-біогенного забруднення поверхневих водних джерел Полтавської області можна пропонувати:

1. Удосконалити технології очищення комунально-побутових та промислових стічних вод. Оскільки саме вони є основним джерелом надходження біогенних елементів у води річки. Адже це власне і $є$ тим чинником, який «запускає» механізм евтрофікації в цілому.

2. Знизити рівень хімізації сільськогосподар- 
ського виробництва.

3. Удосконалювати технологію внесення добрив шляхом зменшення нерівномірності розсіювання добрив.

4. Для зменшення втрати добрив забезпечити належні умови їх зберігання у відповідних приміщеннях та не зберігати фосфатні добрива на відкритому просторі.

\section{БІБЛІОГРАФІЯ}

1. Алмазов О. М. Стік розчинний: солей та біогенних речовин, які виносяться річками УРСР в Чорне море / О. М. Алмазов. - Наук. Зап. Одеської біологічної станції, 1961. - Вип. 3. - С. 99-107.

2. Денисова А.И. Многолетние изменения в стоке биогенных и органических веществ при зарегулировании Днепра / А. И. Денисова. - Гидробиол. журнал, 1978. - Т. 14, №2. - С. 80-86.

3. Нахишна Е. П. Ионный и биогенный сток рек басейна Верхнего Днепра / Е. П. Нахишна. Гидрохим. материалы, 1981. - Т. 78. - С. 57-64.

4. Коненко А. Д. Азот, фосфор и калий в воде рек правобережного Украинского Полесья / А. Д. Коненко, И. Г. Гарасевич, И. Г. Енаки. Гидробиол. журнал, 1974. - Т. 10, №5. - С. 14-20.

5. Журавлёва Л. А. Гидрохимия устьевой области Днепра и Южного Буга в условиях зарегулированного стока / Л. А. Журавлёва. - К. : Наук.
Отже, заходи щодо обмеження використання миючих засобів, своєчасний контроль за очисним обладнанням, його модернізація і орієнтування на Європейські норми якості, жорстка нормативно-правова відповідальність за порушення визначених ГДК дасть змогу регулювати та контролювати потрапляння фосфатів зі стічними водами до поверхневих водойм.

думка, 1988. - $175 \mathrm{c}$.

6. Снежко С. И. Особенности формирования речного стока биогенных веществ на примере бассейна р. Днепр в пределах УССР : автореф. дисс. ... к.геогр.н. / С. И. Снежко. - Ростов-наДону, 1989. - 24 c.

7. Сніжко С. I. Оцінка та прогнозування якості природних вод : підручник / С. І. Сніжко. - К. : Ніка-Центр, 2001. - 264 с. : іл.

8. Регіональна цільова програма розвитку водного господарства та екологічного оздоровлення басейну річки Дніпро в Полтавській області на період до 2021 року. - Полтава, 2013. - 162 с.

9. Голік Ю. С. Екологічний стан басейну річки Дніпро в Полтавській області / Ю.С.Голік, О. Е. Ілляш, О. В. Степова // Вісник Інженерної академії України. - №1. - 2013. - С. 197-200. 